\title{
The Role of UNASUR in the South American Democratic Crises (2008-2015) ${ }^{1}$
}

\section{O Papel da UNASUL nas Crises Democráticas Sul-Americanas (2008-2015)}

DOI: $10.21530 /$ ci.v13n1.2018.729

Elias David Morales Martinez ${ }^{2}$ Mariana P. O. de Lyra ${ }^{3}$

\begin{abstract}
The paper aims to analyze the performance of UNASUR in its first initial phase of activities in cases of democratic crises that happened in South America, during the period 2008-2015. Thus, it examines the cases of Bolivia (2008), Ecuador (2010), Paraguay (2012) and Venezuela (2014-2015). The central hypothesis of this study is that the defense of democracy and its institutions has been incorporated as one of the fundamental elements of the organization. Therefore, UNASUR is guided by political dialogue and consensus building for the maintenance of the democratic order in the South American countries and, consequently, a deepening of the regional integration process. It is argued that UNASUR includes democracy as one of its core values and acts to defend it in unstable situation. Therefore, the strengthening of the organization depends, among other factors, on its ability to resolve conflicts and promote democracy in the continent.
\end{abstract}

Keywords: UNASUR. South America; Regional Integration; Democracy; Democratic Crisis.

1 This research was feasible with the financial support of CNPq / CAPES Agencies.

2 Professor Adjunto Universidade Federal do ABC - UFABC. Professor do Curso de Relações Internacionais e da Pós-Graduação em Ciências Humanas e Sociais UFABC. Dr. Integração da América Latina, PROLAM/USP. Mestre em Relações Internacionais, Universidade de Brasília - UnB. Cientista Político, Universidad Nacional de Colômbia.

3 Professora do Curso de Relações Internacionais - Centro Universitário Tabosa de Almeida - ASCES-UNITA. Doutora em Ciência Política - Universidade Federal de Pernambuco - UFPE. Mestre em Relações Internacionais, Universidade Estadual da Paraíba, UEPB.

Artigo submetido em 14/11/2017 e aprovado em 13/03/2018. 


\section{Resumo}

O artigo objetiva analisar a atuação da UNASUL na sua fase inicial de atividades em casos de crises democráticas que aconteceram na América do Sul no período 2008-2015. Para tanto, examinam-se os casos da Bolívia (2008), Equador (2010), Paraguai (2012) e Venezuela (20142015). A hipótese central deste estudo é que a defesa da democracia e de suas instituições tem sido incorporada como um dos elementos basilares da organização. Portanto, a UNASUL age pautada no diálogo político e geração de consenso para a manutenção da ordem democrática nos países sul-americanos e, consequentemente, aprofundamento do processo de integração regional. Defende-se que a UNASUL incorpora a democracia como um dos seus valores centrais e age para defendê-la em situação de instabilidade. Conclui-se que o fortalecimento da organização está fundamentando em sua capacidade de resolver conflitos. Além disso, o aprofundamento do processo integrativo e o futuro da organização dependem do avanço das democracias sul-americanas.

Palavras-chave: UNASUL. América do Sul; Integração Regional; Democracia; Crises Democráticas.

\section{Introduction}

The Union of South American Nations (UNASUR) was created in 2008, the result of Brazil's proposal for regional integration. Since its beginning, the organization has drawn attention to a the multiplicity of issues. Given its multidisciplinary vocation, the institution includes thematic councils on various issues, from energy integration to health.

Among the issues that the organization deals with, defense of democracy is one of the most prominent. In 2010, member countries approved the Additional Protocol to the Constitutive Treaty of UNASUR on the Commitment to Democracy (known as the democratic clause), indicating the importance of this issue for the organization. Thus, this study seeks to analyze how UNASUR has acted in defense of democracy at the regional level. It explores UNASUR intervention in four cases of turmoil in the democratic order of South American countries: Bolivia (2008), Ecuador (2010), Paraguay (2012) and Venezuela (2014/2015).

The central hypothesis is that the defense of democracy has been incorporated as one of the basic elements of the organization. Therefore, the UNASUR acts based on political dialogue and consensus building for the maintenance of the democratic order in South American countries, strengthening regional integration. 
The methodology used in this research is the interpretative, based on the documental and bibliographic analysis. The paper is divided in three main sections. The first section deals with the origins of UNASUR and the way its actions have been outlined since 2008. The second one discusses the Additional Protocol to the Constitutive Treaty of UNASUR on the Commitment to Democracy, institutional framework for defense of democracy. Finally, the third section contains the analysis of the four cases. The conclusion of the paper is that the strengthening of the organization is based on its ability to resolve conflicts. In addition, the deepening of regional integration and the Organization's future depends on the stability of the South American democracies.

\section{UNASUR: origins and modus operandi}

As a reformulation of South American Community of Nations (CASA), the UNASUR has deep roots in the Cusco Declaration (2004), reaffirming that the South American countries "have faced common internal and external challenges and they present a political and philosophical thought born from their tradition"4 (BRAZIL, 2005, p. 95, free translation). Therefore, they seek "the convergence of political, economic, social, cultural, and security interests, as a potential factor in their strengthening and the development of their internal capabilities for better international insertion"5 (BRAZIL, 2005, p. 96, free translation).

Saraiva (2012) argues that the establishment of the UNASUR may be observed from an optimistic perspective; not simply as a result of the emptying of the CASA. For the author, the UNASUR has been a real and symbolic advance, which allowed the construction of consensus and action in regional crises, becoming a mechanism for intra- and extra-regional negotiations. According to Saraiva (2012, p. 97-98, free translation):

The change [from CASA] to UNASUR was the result of the Venezuelan government claims articulated with the political will of Lula's government and the organization became the main multilateral action channel. It is a

4 "têm enfrentado desafios internos e externos comuns e apresentam um pensamento político e filosófico nascido de sua tradição” (Brazil, 2005, p. 95).

5 "convergência de interesses políticos, econômicos, sociais, culturais e de segurança, como um fator potencial de seu fortalecimento e desenvolvimento de suas capacidades internas para sua melhor inserção internacional” (Brazil, 2005, p. 96). 
mechanism that emphasizes the political dimension of the Brazilian policy in the region and through which the Brazilian diplomacy has built consensus among the neighboring countries to deal with difficult situations, and always seeking to occupy a prominent role. ${ }^{6}$

The UNASUR was born in a new global geopolitical context, in which the US is concentrated on its war on terror, following the September 11 attacks. The change in the strategic dynamics of superpower impacted on regional relations. Again, South America has been excluded from the US priorities list as its geopolitical focus turned to the Middle East. This changing scenario - along with the relative failure of the neoliberal policies of the 1990s, which led many South American countries to crisis - has allowed the emergence of new leaders, especially from the left and developmental bias.

The new regional panorama has enabled changes in the political scene. It has led South America to the protagonist of its own development. Thus, two markedly different perspectives emerged. On the one hand, "the geostrategic and military vision full of ideological elements, illustrated by Hugo Chavez's foreign policy" (SERBIN, 2009, p. 6, free translation). ${ }^{7}$ On the other hand, the Brazilian perspective, whose guiding element is the perception that South America needs a "multidimensional development based on productive, industrial and commercial development" (SERBIN, 2009, p. 7, free translation) ${ }^{8}$.

Although they are not mutually exclusive visions, Brazil and Venezuela represent different positions for the development of South America, particularly regarding the relationship with the US. In accordance with Serbin (2009), Chavez represented the direct confrontation with Washington, seeking to create an anti-hegemonic network among countries of the region. However, the Venezuelan strategy is contradictory due to Venezuela's dependence on the US consumer market. Chavez's position was strongly based on oil diplomacy, in which money from the oil trade was the basis for actions and regional prominence of Venezuela. On the other hand, Brazil "sought the development of a peaceful coexistence

\footnotetext{
6 "A mudança [de CASA] para Unasul foi o resultado de reivindicações do governo venezuelano articuladas com a disposição política do governo Lula e a organização se converteu no principal canal de ação multilareal. É um mecanismo que enfatiza a dimensão política da política brasileira para a região e através do qual a diplomacia brasileira tem construído consensos entre os países vizinhos para lidar com situações difíceis, e buscando sempre ocupar um papel de destaque” (SARAIVA, 2012, p. 97-98).

7 “visão geoestratégica e militar carregada de elementos ideológicos, ilustrada pela política exterior de Hugo Chávez” (SERBIN, 2009, p. 6).

8 “multidimensional e [baseado] no desenvolvimento produtivo, industrial e comercial” (SERBIN, 2009, p. 7).
} 
with the United States and recognition as a partner in a relationship that does not threaten its regional and global aspirations" (SERBIN, 2009: p. 7, free translation) ${ }^{9}$

During the opening speech of the 63rd General Assembly of the United Nations, former President of Brazil, Lula da Silva, said:

In my continent, the UNASUR was created last May, as the first treaty - after 200 years of Independence- that congregates all South American countries. This new political union will coordinate the region's countries in terms of infrastructure, energy, social policies, complementarities of production, finances and defense (SILVA, 2008, p. 3, free translation). ${ }^{10}$

The Constitutive Treaty of UNASUR, in Article 2, takes the responsibility to strengthen the South American democracies, proposing to build a reliable area, stability and peace. Thus, the UNASUR aims to break the South American history, marked by coups and abrupt process of succession of power in an attempt to achieve a virtuous cycle of development and political stability in the region. Figure 1 outlines the cycle desired by UNASUR, in which three elements (integration, dialogue and democracy) feed and strengthen each other.

Figure 1. Virtuous cycle desired by UNASUR

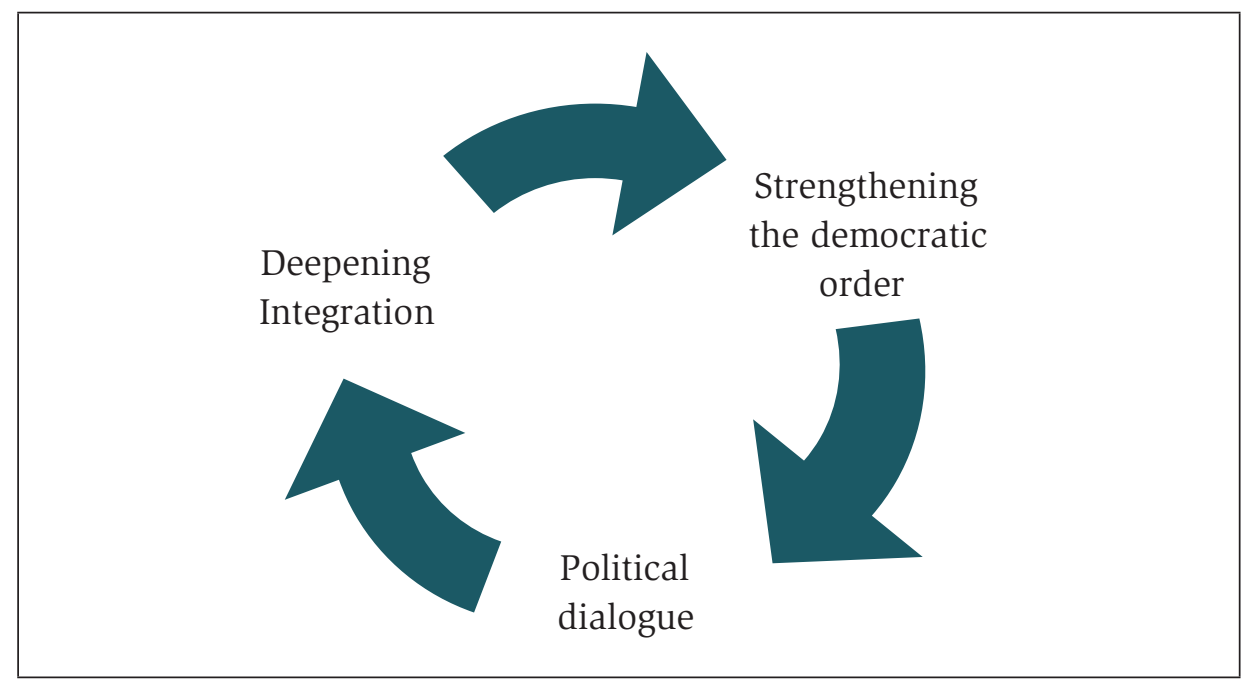

Source: elaborated by authors based on the Constitutive Treaty of UNASUR.

9 "procurou o desenvolvimento de uma convivência pacífica com os EUA e o reconhecimento como interlocutor em uma relação que não ameace suas aspirações regionais e globais” (SERBIN, 2009, p. 07).

10 "Em meu continente, a Unasul, criada em maio deste ano, é o primeiro tratado - em 200 anos de vida independente - que congrega todos os países sul-americanos. Com essa nova união política, vamos articular os países da região em termos de infraestrutura, energia, políticas sociais, complementaridade produtiva, finanças e defesa" (SILVA, 2008, p. 3). 
In the 1990s, several countries in the region (Bolivia, Venezuela, Peru, Ecuador, and others) were affected by attempts to destabilize the democratic order. South America was space for political crises and difficulties in consolidating young democracies. In this sense, after the establishment of UNASUR, the organization began to mediate crises in defense of the legitimacy of governments, institutions and the democratic system as a whole.

In 2008, shortly after its creation, the UNASUR had to deal with the Bolivian crisis, triggered by the approval of the Hydrocarbons Law, which caused instability to Evo Morales's government. This was one of the first actions of the organization in defense of democracy, which was followed by diplomatic management of crises in Honduras, Ecuador, Paraguay and Venezuela.

In order to fulfill the objectives of UNASUR, a politically stable region is necessary. This includes the protection and promotion of democracy. From this perception, in 2010, an additional protocol was established to deal strictly with democratic order in South American countries, "the Additional Protocol to the Constitutive Treaty of UNASUR on the Commitment to Democracy"11, which is explored in the next section.

In addition to this mechanism, in 2012, the UNASUR created its Electoral Council (CEU) in order to cooperate, integrate and share good practices in relation to electoral processes as well as observing and monitoring elections, when requested by a Member State.

In this sense, the UNASUR has established a institutional structure with the task of supporting one of the most basic elements of a democratic regime: free elections. Also, it has incorporated to its institutional apparatus technical and political instruments to strengthen the procedures for the consolidation of young democracies in the region.

The emergence and consolidation of UNASUR would not have been possible without the values expressed in the external policies of the South American countries that it was feasible to carry out an exclusive integration process for the region. The possibility of harmonizing these interests, searching for a South American identity, reinforced the projects derived from progressive governments, which pushed integration strategies at a different level to the previous integration processes.

11 From this point on, the term Protocol on Democratic Commitment will be used to refer to the Additional Protocol to the Constitutive Treaty of UNASUR on the Commitment to Democracy. 
Sarti (2014) argues that this new orientation given to Latin American integration processes, was possible with the arrival of more progressive governments in the 2000s, which initiated a virtuous cycle in regional politics. The strategy of seeking the sovereign insertion of the region in order to overcome the subaltern role of the periphery, in which it was relegated from the beginning, it focused on the implementation of autonomy foreign policy and a reinvigoration of democratic institutions associated with the purpose of economic and social development. In fact, this came to constitute a watershed on the continent.

Guimarães (2014) understands this autonomy as a condition of possibility for sovereign development through the building of prosperous, democratic and autonomous economic and political blocs in South America. For this reason, strengthening democracy in the region becomes necessary for regional and emancipatory public policies to take place with broad action.

In this perspective, Nery (2016) emphasizes that due to this new context at the beginning of the 21st century, South American countries' foreign policies adopted more autonomous decisions, which allowed the construction of a different regionalism marked by heterogeneity and political character of emancipation before the constant American influence. UNASUR has thus become a multilateral space for political coordination and cooperation based on the ideological plurality of members. On the one hand, it may be perceived as a place of resistance to US power, on the other hand it offers an environment for concerting regional positions about defense of the interests of the region and the pursuit of the collective good.

Likewise, for Vigevani and Ramanzini (2014) this new South American perception of collective space led to a vision that the region is exclusively entitled to solve controversies and crises, which is based on the autonomy of the external policies. In the Brazilian case, the objective was to strengthen cooperation on defense and security issues, as well as to establish a counterpoint to the influence of the USA, mainly to Andean countries. The point that the authors emphasize is that the countries of the region did not have a history of cooperation in security and defense because different interpretations about those subjects that were subordinated to relation with the USA or the regimes and institutions dominated by this country.

Once analyzed the emergence of UNASUR and the factors that allowed its implementation, it is essential to proceed to the study of the relevance of democracy in the process of political integration,conciliation and resolution of crises among South American countries. 


\section{The Democratic Clause of UNASUR}

Since its creation, the UNASUR has dealt with political problems in the region. Before tensions in the continent, political leaders have perceived the need to create a mechanism to strengthen the South American democracies. Democratic crises in Bolivia (2009) and Ecuador (2010), for example, were essential for the adoption of a "democratic clause" by the organization.

In 2010, during the South American Summit in Georgetown, Guyana, it approved the "Additional Protocol to the Constitutive Treaty of the UNASUR on Commitment to Democracy". Such a mechanism would be applied to member states in cases of "break or rupture threatening the democratic order, violation of the constitutional order or any situation that threatens the legitimate exercise of power and the validity of democratic values and principles" (UNASUR, 2010a, p. 1).12

Soon after the establishment of the Protocol on Democratic Commitment, Hugo Chavez - former president of Venezuela - said that the instrument intended to prevent "coup attempts", stating that "it is a protocol to support democracy and the attack on coups and destabilizing movements that continue to be a threat to the region" (CHÁVEZ 2010, p. 1, free translation). ${ }^{13}$ On the same occasion, Rafael Correa, President of Ecuador, said that the democratic clause is a "shielding and protection against coups in member countries, [those who try to] take the power of a de facto government will know they will face total rejection from the region" (CORREA, 2010, p. 1). ${ }^{14}$

At the regional level, enforcement tools and commitment to democracy are not exclusive of UNASUR. The Rio Group, in 1986, affirmed "the need to join forces and capabilities to find region's own solutions [...] and boost the independent and sustainable development [...] unites us to the purpose of strengthening democracy from a growing process of cooperation and integration" (FLACSO, 2008, p. 17). ${ }^{15}$ The Common Market of the South (MERCOSUR), in 1996, reaffirmed that "the solidarity

12 "ruptura ou ameaça de ruptura da ordem democrática, de uma violação da ordem constitucional ou de qualquer situação que ponha em risco o legítimo exercício de poder e a vigência dos valores e princípios democráticos” (UNASUL, 2010a, p. 1).

13 “é um protocolo de apoio à democracia e de ataque aos golpes de Estados e movimentos desestabilizadores que seguem sendo uma ameaça à região, sobretudo à Bolívia, Equador e Venezuela” (Chavez, 2010, p. 1).

14 "blindagem e proteção contra o golpismo nos países membros, [aqueles que tentarem] tomar o poder de um Governo de fato saberão que terão que enfrentar o repúdio total da região” (CORREA, 2010, p. 1).

15 "necessidade de unir esforços e capacidades para encontrar soluções próprias [...] e impulsionar o desenvolvimento independente e sustentável [...] nos une ao propósito de fortalecer a democracia a partir de um crescente processo de cooperação e integração” (FLACSO, 2008, p. 17). 
of the American states and the high aims which it pursues require the political organization of those states to be based on effective exercise of representative democracy" (MERCOSUR, 1996, p. 1).16 In addition, the Presidential Declaration on Democratic Commitment in MERCOSUR states that democracy is essential condition for participation in the group and provides for the suspension of infringing States.

In 2001, the Organization of American States (OAS) also established a "democratic clause": the Inter-American Democratic Charter, which lifted democracy to the level of rights of the American people. Miranda (2013) argues that the Protocol on the Democratic Commitment and the Charter have similar spirits. The difference lies in the instruments that each document has to strengthen democracy. While the Inter-American Democratic Charter provides only diplomatic and suspension actions, the Protocol on Democratic Commitment sets out a number of different measures, ranging from diplomatic crisis management to economic sanctions to infringers governments.

Thus, the Protocol on Democratic Commitment aims to provide the UNASUR with institutional mechanisms for peaceful resolution of regional tensions in situations of rupture or threat to the democratic order in South American countries. It also allows the rapid consultation between members to decide about sending diplomatic missions and charging penalties on infringers States, in order to restore democratic regular process.

In this sense, the Protocol on Democratic Commitment guarantees the respect for sovereignty and territorial integrity of States, and provides several punishments to lawbreakers countries such as:

a) suspension of the right to participate in various organs and bodies of UNASUR; b) total or partial closure of land borders, including suspension and / or restriction of trade, air and shipping, communications, energy supplies, services and supplies; c) promote the suspension of the affected State in the context of other regional and international organizations; d) promote, together with third countries or regional blocs, the suspension of the rights and / or benefits of the affected state, derived from cooperation agreements; and e) adoption of additional political and diplomatic sanctions (UNASUR, 2010a, p. 2, free translation). ${ }^{17}$

16 "a solidariedade dos Estados americanos e os altos fins que ela persegue exige a organização política dos mesmos com base no exercício efetivo da democracia representativa” (MERCOSUL, 1996, p. 1).

17 a) suspensão do direito de participar dos diversos órgãos e instâncias da UNASUL; b) fechamento parcial ou total das fronteiras terrestres, incluindo a suspensão e/ou limitação do comércio, tráfego aéreo e marítimo, comunicações, abastecimento de energia, serviços e suprimentos; c) promover a suspensão do Estado afetado 
Therefore, The Protocol on Democratic Commitment, therefore, is a milestone in the institutional development of UNASUR, since it is a binding mechanism (as well as the Constitutive Treaty). It is a protocol that needs to be validated by the national parliaments, indicating acceptance by majority institutions of the South American countries. Moreover, Miranda (2013,p. 198-199, free translation) calls attention to the possible uses:

[The Protocol on Democratic Commitment] is based on a constitutional principle that assumes as democratic governments elected in legal manner, but also leaves open the possibility of application of the 'democratic clause' in case of risk to the effectiveness of 'democratic values' and 'legitimate exercise of power'.18

The Protocol on the Democratic Commitment enhances the legitimacy of elected governments as expression of people's will, however, without neglecting minority rights. The document reiterates the commitment to protect the rule of law and its institutions, the democratic order and fundamental freedoms, including freedom of expression and opinion. These elements are considered essential and fundamental not only for the development of regional integration, but also for participation in the UNASUR (UNASUR, 2010a).

Finally, the approval of the Protocol on the Democratic Commitment means regional commitment to democratic order. Democracy seems to work as an element that foster regional integration; and its defense is part of the set of actions to deepen integration promoted by the UNASUR.

\section{The UNASUR and crises in the South American democracies (2008-2015)}

The defense of democracy seems to support the proposal of UNASUR and finds resonance to analyze activities undertaken by the organization in mediating disputes in the South American States. However, it is necessary to make a brief analysis on what democracy is, and the concept of democracy that the UNASUR

no âmbito de outras organizações regionais e internacionais; d) promover, junto a terceiros países ou blocos regionais, a suspensão dos direitos e/ou benefícios do Estado afetado, derivados dos acordos de cooperação dos quais fizer parte; e e) adoção de sansões políticas e diplomáticas adicionais (UNASUL, 2010b, p. 2).

18 [o Protocolo] parte de um princípio constitucionalista que pressupõe como democráticos governos eleitos nos moldes legais, mas também deixa em aberto a possibilidade de aplicação da 'cláusula democrática' em casos de risco à vigência dos ‘valores democráticos’ e ao ‘legítimo exercício de poder’ (MIRANDA, 2013, p. 198-199). 
manifests to defend like its own cause, in order to guarantee the success of the process of integration between the regional countries. Although the cases analyzed allow us to observe that democracy in South American countries is constantly in process of maturation. There is a perception of possible fragilities distorting the democratic experience, because its understanding is limited only to the matter of the breach of constitutionality, that is not the perception used in this article.

The current South American case denotes a resumption of the democratization of its governmental regimes is directly related to the difficulties in all spheres of the social coexistence during the military regimes in the second half of the twentieth century. The re-democratization of political institutions allowed the inclusion of deep debates on the classic division of powers from the new realities that the Latin American countries came to understand.

Hermet (2002) argues that during the process of democratic transition in the region, there was a significant change in ideological perception by most Latin American citizens. This perception consisted that democracy would undoubtedly bring benefits beyond previous regimes. However, the new democratic governments have faced enormous problems implementing strategies that lead to a better quality of life for citizens.

In this sense, for Guimarães, Barros and Pinto (2014) the problems that Latin American countries have faced in the process of democratization are related to the specific characteristics of the region. It is worth noting that the new democracies tend towards a certain insulation of politics, in addition to focusing on the administrative and procedural dimensions, in detriment of the quality of mechanisms for the incorporation of identities and strategies of the new social actors, who were traditionally excluded and marginalized in their possibilities of participation and exercise of citizenship in the process of democratic consolidation.

Therefore, we believe that UNASUR through the Democratic Clause and the Protocol perceives as a fundamental element the defense of this comprehensive democracy, not limited to the existence of elections and participation in the decision-making process, but also to the community process of social integration to strengthen the institutionalization of the Rule of Law and reflective cooperation between the countries of the Region. ${ }^{19}$

19 Honneth (2001, p. 65-67) argues that the Habermasian view of democracy can be complemented by Dewey's postulates on democratic proceduralism through the model of social cooperation, since the relationship between state and law, there is a solidary citizenship with the possibility of organizing society through processes of communicative consultation and implementation of institutional programs that lead to the strengthening of institutional procedures. 
Thus, this section explores briefly four events in which UNASUR has attempted to contain tensions concer ning democratic order in South American countries. Chart 1 below presents the general information about the crises, such as actors involved, period, motivations, among others. It can be observed that the different crises have a thematic scope and do not necessarily refer to the breach of constitutionality.

Chart 1. UNASUR and democratic crises in the region (2008 - 2015)

\begin{tabular}{|c|c|c|c|c|}
\hline COUNTRY & YEAR & KEY ACTORS & $\begin{array}{c}\text { MAIN } \\
\text { MOTIVATIONS }\end{array}$ & $\begin{array}{c}\text { MAIN ACTIONS } \\
\text { DEVELOPED BY THE } \\
\text { UNASUR }\end{array}$ \\
\hline Bolivia & 2008 & $\begin{array}{l}\text { Demonstrators } \\
\text { for and against } \\
\text { Evo Morales' } \\
\text { government. }\end{array}$ & $\begin{array}{l}\text { Dissatisfaction } \\
\text { with the Law of } \\
\text { Hydrocarbons. }\end{array}$ & $\begin{array}{l}\text { - } \text { Conflict Mediation. } \\
\text { - Support for Bolivia's } \\
\text { democratic order. } \\
\text { - Declaration of La } \\
\text { Moneda. } \\
\end{array}$ \\
\hline Ecuador & 2010 & $\begin{array}{l}\text { Unsatisfied military } \\
\text { and government } \\
\text { forces. }\end{array}$ & $\begin{array}{l}\text { Changes in budget } \\
\text { and management of } \\
\text { public safety. }\end{array}$ & $\begin{array}{l}\text { - Extraordinary meeting } \\
\text { of heads of state } \\
\text { - Support for Ecuador's } \\
\text { democratic order. } \\
\text { - Elaboration of the } \\
\text { Additional Protocol to } \\
\text { the Constitutive Treaty } \\
\text { of the UNASUR on } \\
\text { the Commitment to } \\
\text { Democracy. }\end{array}$ \\
\hline Paraguay & 2012 & $\begin{array}{l}\text { Conservative and } \\
\text { leftist social sectors. }\end{array}$ & $\begin{array}{l}\text { Dissatisfaction of } \\
\text { some sectors with } \\
\text { policies of former } \\
\text { President Fernando } \\
\text { Lugo. }\end{array}$ & $\begin{array}{l}\text { - } \text { Meeting of members of } \\
\text { UNASUR. } \\
\text { - Suspension of Paraguay } \\
\text { from UNASUR. }\end{array}$ \\
\hline Venezuela & 2014-2015 & $\begin{array}{l}\text { Nicolas Maduro's } \\
\text { government and } \\
\text { opposition forces. }\end{array}$ & $\begin{array}{l}\text { Dissatisfaction } \\
\text { with Maduro's } \\
\text { administration. }\end{array}$ & $\begin{array}{l}\text { - Conflict Mediation. } \\
\text { - Mission. } \\
\text { - Pressure for } \\
\text { parliamentary elections } \\
\text { in } 2015 \text {. } \\
\text { - Monitoring of the } \\
\text { elections. }\end{array}$ \\
\hline
\end{tabular}

Source: elaborated by the authors based on information available in UNASUR website (www.unasursg.org) 
Thus, the crises in Bolivia, Ecuador, Paraguay and Venezuela will be analyzed in more detail below, in order to better understand how UNASUR has conducted its regional activities in matters related to the defense of the democratic order of the South American countries that experienced crises in the period 2008-2015.

\section{The Bolivian crisis (2008)}

Bolivia, under Sánchez de Lozada's administration (2002-2003), had been suffering from intense protests related to the sale and use of hydrocarbons which became known as the "gas war". In 2005, Evo Morales was elected with strong support from the Bolivian social and indigenous movements. Based on a political platform that favored a strategy for defense of the national interest, Morales proposed review and renegotiation of hydrocarbon exploration contracts with foreign companies. Moreover, the president of Bolivia projected the redistribution of royalties arising from natural gas and oil exploration, reducing the share of resources for producers states such as Pando and Santa Cruz.

President Morales has been confronted in two ways: national and international. The nationalization of hydrocarbons was rejected by investors and international companies, creating problems with the governments of Spain, England and Brazil. Domestically, the president faced problems with autonomist groups, calling for more freedom from central government for some departments. It added to this controversy and discussions on the reformulation of laws on the maximum size of farms in the Andean country (DOMINGUES, 2008).

The crisis resulted in increased demonstrations against Morales, led by the eastern departments of Bolivia. There were clashes between pro and anti-government demonstrators, causing the death of dozens of people and subsequently the state of siege. The opponents of Morales's government sought the repeal of the Hydrocarbons Law.

Upon request by La Paz in April 2008, Brazil, Argentina and Colombia formed the "Friends Group" to facilitate dialogue between Morales' administration and internal opposition forces. However, the effort was not fruitful. Referendum held in the same year approved the autonomy of the department of Santa Cruz, which was promptly rejected by the Bolivian president on the grounds of unconstitutionality. After the referendum of Santa Cruz, three other departments also consulted on the autonomy of the regions. In all cases, it was observed the significant support from the local population to greater independence from Bolivia's central government. 
Domingues (2008) stresses that to call - through a presidential decree- a referendum to approve a new constitution brought more instability to the Bolivian political scene. The National Electoral Court did not accept the summons, stating that consultations should firstly be submitted to the Congress. Thus, the situation became more radicalized, with clashes between government and opposition forces.

Due to the worsening of the crisis and the expansion of violence, the US diplomat Philip Goldberg was expelled from Bolivia on charges of helping government opponents and planning a coup. As a result, Washington expelled the Bolivian ambassador, Gustavo Guzman. In solidarity to Bolivia, Venezuela also expelled the US ambassador and the presidents of Nicaragua and Honduras canceled official meetings with Washington. Therefore, the crisis took hemispheric proportions.

When internal conflict intensified and separatist groups emerged,, the UNASUR proposed to establish a space for dialogue, while ensuring regional support for the sovereignty of Bolivia. The pro-tempore president, Michelle Bachelet (2008-2009), convened a special meeting in order to present the UNASUR as mediator of the conflict. On that occasion, UNASUR reached a political concert that produced the Declaration of La Moneda, strengthening - at the same time - the South American democratic order and the newly created organization.

The Declaration of La Moneda was a milestone for the UNASUR. The document expressed full regional support for Morales' government and condemned any attempt at destabilization, coup or territorial division of Bolivia. Moreover, it created two committees to assist in containing the crisis. The first group would develop a fair investigation of deaths during confrontations of divergent forces. The second group, coordinated by Chile, had the task of monitoring negotiations between representatives of the Bolivian government and opposition.

After support from the extraordinary meeting, Morales thanked the UNASUR for "the firm position of defending democracy and unity of the people of Bolivia" (MORALES, 2008, p. 1, free translation) ${ }^{20}$, and stressed that "for the first time in Latin American history, South American countries decide among themselves to solve their own problems" (MORALES, 2008, p. 1, free translation) ${ }^{21}$. Then Morales met with opposition. They signed guidelines to end the crisis, which included a period of two days for negotiations, investigation of killings during the

20 “pela posição firme de defender a democracia e a unidade do povo da Bolívia” (MORALES, 2008, p. 1).

21 "pela primeira vez na história latino-americana, os países da América do Sul decidem entre si resolver seus próprios problemas” (MORALES, 2008, p. 1). 
clashes, and indication of The UNASUR, the European Union (EU), the Catholic Church and the United Nations (UN) as facilitators of negotiations. The choice of mediating organizations stands out to exclude the OAS, demonstrating the decrease in strength and influence of the hemispheric organization in the South American issues.

For Serbin (2009, p. 11, free translation) the Declaration of La Moneda was "the first successful intervention of UNASUR in internal affairs of one of its member states". 22 The author argues that the work in Bolivia was based on three elements proposed by Brasilia and accepted by the other members of UNASUR; they are:

a) the intervention should be called by the democratically elected government of Bolivia; b) seek to consolidate the existing democratic institutions and promote dialogue between the conflicting parties; c) avoid any reference or questioning the role of the US (SERBIN 2009, p. 12, free translation). ${ }^{23}$

The management of the Bolivian crisis was a positive intervention of the UNASUR, helping not only the consolidation of South American democracies, but also the real and symbolic advance of South America as manager of its problems. The UNASUR performance showed the relative maturity and autonomy of the region and the search for consensus of the South American governments in cases of local instability. In addition, the successful action of UNASUR enabled its institutional strengthening - the organization was created in the same year of the bolivian crisis - and the deepening of regional integration.

\section{Ecuador's crisis (2010)}

When Rafael Correa initiated his presidency, in 2007, a series of reforms were implemented: from redirection of the Ecuadorian foreign policy to land reform. In this context, it created a stormy atmosphere, with tensions with political parties, public opinion, unions and social movements.

Changes promoted by Correa hit mainly the security sector. He started to investigate complaints of human rights violations by the National Police, what

22 "primeira intervenção bem-sucedida da UNASUL nos assuntos internos de um dos seus Estados membros" (SERBIN, 2009, p. 11).

23 “a) que a intervenção fosse convocada pelo governo eleito democraticamente da Bolívia; b) que buscasse consolidar a institucionalidade democrática vigente e promover um diálogo entre as partes em conflito; c) que evitasse qualquer referência ou questionamento quanto ao papel dos EUA” (SERBIN, 2009, p. 12). 
generated dissatisfaction in the military sector. In 2010, Correa sent to Parliament a bill that would change the public service (Organic Public Service Law). This project eliminated bonuses for coordination and promotion of the military, but included compensation for overtime. Given the dissatisfaction of the military, the Ecuadorian Congress proposed to negotiate with the category. However, Correa vetoed the negotiation affirming that there could be no exceptions.

On 30 September 2010, the situation radicalized. The Police of the 1st Regiment of Quito, the Ecuadorian capital, refused to leave the police station and provide public security services. Soon, other regiments of Quito and other regions also joined the protest. That same day, the military blocked National Unity Bridge, in Guayaquil, and closed Quito's international airport. Avenues were closed, schools dismissed their students, merchants closed their activities, the public transport stopped and public buildings were evacuated because of the violence - looting, theft etc. - that occurred in the absence of the police (CEPEDA; PAZ, 2011).

Given the chaotic situation, Correa decided to head to the police base. In an attempt to leave the location, Correa was the target of insults. He decided not to withdraw, since he was the President of the country and head of the military. This decision deepened the crisis, and Correa got caught in the military hospital on the other side of the base. The place was taken by demonstrators who threw tear gas and chanted slogans. At the same time, protests took place in Congress and clash between opposing and pro-government forces (CEPEDA; PAZ, 2011).

There is no consensus on whether or not there was an attempted coup, mainly due to unknown leadership or real proposals to replace the president. In any case, the crisis was serious and showed real danger to Correa's life, as well as to the democratic order.

The Secretary General of UNASUR, Nestor Kirchner (between May and October 2010), brought together the South American presidents, in Buenos Aires, to support Correa and defend the democratic order in Ecuador. The UNASUR strongly condemned the situation, treated as a coup by the organization. Furthermore, it was articulated a visit of Member States' foreign ministers to Quito. The UNASUR requested that the events were explained and the perpetrators punished (CEPEDA; PAZ, 2011).

On October 1, 2012, The UNASUR presented the Declaration of Buenos Aires on the situation in Ecuador. In the document, the organization listed six points in which it condemned the crisis and reaffirmed the legitimacy of the Ecuadorian president. According to the Declaration of Buenos Aires: 
The Heads of State and the Government of UNASUR [...] claim that their respective governments energetically reject and will not tolerate, under no circumstances, any new challenge to the institutional authority or attempted coup to civil power legitimately elected; and warned that in case of new breaches of constitutional order, shall take concrete and immediate measures such as border closures, suspension of trade, air traffic and the provision of energy services and other supplies (UNASUR 2010b, p. 1, free translation). ${ }^{24}$

Due to the crisis experienced by Ecuador, the UNASUR had new space to consolidate the guiding principles of its activities. During this episode, the organization quickly summoned its members to discuss measures for strengthening the democratic order in the region. It was Ecuador's crisis that highlighted the need for a regional instrument to strengthen democracy. Moreover, in December 2010, during the annual meeting, the Additional Protocol to the Constitutive Treaty on the Commitment to Democracy was established, which ensured "concrete measures to be adopted by Member States of UNASUR in situations of rupture of the constitutional order" (ISAGS 2011, p. 1, free translation). ${ }^{25}$

The immediate regional reaction and especially consensus were an important element for the maintenance of the democratic order in the Andean country. The organization was responsible for establishing dialog and demonstrated that the other South American countries would not connive with ruptures or cope; and would apply sanctions to those that bring risk to democracy. The UNASUR, therefore, showed strength and ability to solve regional problems. The episode was also important to strengthen democracy as one of the core values of the institution and to the development of mechanisms to defend it.

\section{The Paraguayan crisis (2012)}

Paraguayan political crisis (2012) is deeply rooted in the agrarian question. The country is marked by conflicts between peasants, landless movement, and large landowners. The victory of Frente de Esquerda, led by Fernando Lugo in

24 As Chefas e Chefes de Estado e de Governo da UNASUL [...] afirmam que seus respectivos Governos rechaçam energicamente e não vão tolerar, sob nenhum conceito, qualquer novo desafio à autoridade institucional nem tentativa de golpe ao poder civil legitimamente eleito; e advertem que, em caso de novas quebras da ordem constitucional, adotarão medidas concretas e imediatas, tais como fechamento de fronteiras, suspensão do comércio, do tráfego aéreo e o fornecimento de energia, serviços e outros suprimentos (UNASUL, 2010b, p. 1).

25 "medidas concretas a serem adotadas pelos Estados Membros da UNASUL em situações de ruptura da ordem constitucional” (LUGO, 2012, p. 1). 
2008, put an end to 60 years of Colorado Party domination. Its political platform was based on an agenda that favored land reform, which should be carried out “without traumatic or violent processes" (LUGO, 2012, p. 1, free translation).

During the brief government of Lugo (2008-2012), there were several clashes between large landowners and peasant movements, which led to the end of his presidency. In 2010, Lugo declared state of emergency in the North due to constant land invasions and attacks by the Paraguayan People's Army (EPP), which has strong connections with the FARC (GIRALDI, 2013).

Political instability in Paraguay worsened in June 2012, when eleven peasants and six policemen were killed and dozens of people were injured during conflicts in farm fields Morombi, to the northeast of Asuncion. The ownership of land was attributed to the former senator from Colorado Party - opposition to Lugo's government - Blas Riquelme, who was accused of illegally getting hold of the property during Alfredo Stroessner's dictatorship, also from Colorado Party.

Tensions resulted in the resignation of the Interior Minister (Liberal Radical Autêntico Party, an important supporter of Lugo's government). However, it was found that the property in dispute did not belong to Blas Riquelme, leading Paraguayan President to seek closer ties with the Colorado Party, offering them the Ministry and therefore losing the support of the Liberal Party.

In only four days (between 15 and 19 June 2012), tensions intensified, culminating in the beginning of Lugo impeachment on June 20th, 2012. The Paraguayan legislature based on Article No. 225 of the Constitution and claimed "poor performance of duties" to justify the deposition of Lugo. The charges related to six major elements: 1) links with social movements, which intensified land invasions; 2) authorization of Engineering Command of the Armed Forces in 2009 for political act; 3) Nacunday case in which Lugo was accused of being condensending with land invasions; 4) explosion of violence related with weaknesses in public security policy; 5) conflict in Curuguaty, which resulted in the death of 17 people; and 6) support for Ushuaia II protocol within MERCOSUR without parliamentary ratification (GAIO, 2012).

On June 22, 2012, seven days after the killings in Curuguaty and two days after the opening of impeachment, President Lugo was ousted and his deputy, Federico Franco of the Authentic Radical Liberal Party, took over the presidency of Paraguay. Lima (2012, p. 1, free translation) argues that the fast impeachment is a type of "neogolpismo". Lima (2012) indicates that the Paraguayan case sets a dangerous precedent: the facility to unseat presidents democratically elected 
through processes that have legal or institutional appearance. The coup in Paraguay took on distinct characteristics of coups (and attempts) that hit South America during the 20th Century and early 21st. For Lima (2012, p. 1, free translation):

[neo-coup requires] less use of violence than in the past; civilian leadership, and may rely on indirect involvement of the military; maintenance of some institutional appearance; absence of overt participation of a power (USA); and seeks to resolve quickly any kind of social or serious political standoff. 26

Franco's government was hailed as legitimate by the United States, Canada, Spain and the Vatican. Nevertheless, it triggered a counter reaction in the region, where many countries classified it as a democracy breakdown in Paraguay. In this sense, the South American countries did not recognize the legitimacy of the impeachment and declared support for Lugo.

Before the decision of the Paraguayan Congress, UNASUR Member States were gathered in Rio de Janeiro for the Rio +20 Conference. During the event, it was decided the immediate dispatch of a mission to Asunción in support of President Lugo. After hearing the Paraguayan President, the UNASUR defended the democratic order and did not recognize the impairment process is based on three main arguments: 1) failures in the charges; 2) disregard to due process; and 3) curtailment of the right to legal defense.

Alí Rodriguez, General Secretary of UNASUR (2012-2014), accompanied UNASUR's mission in Asuncion, and said that opposition had no interest in ending the political crisis, and the situation configured a coup. Shortly before the formal announcement of Lugo's impeachment, Rodriguez said that UNASUR "could not give a different direction to events. [...] What we saw was that they had already made a decision, a coup" (RODRIGUEZ, 2012, p. 1, free translation). ${ }^{27}$ Speaking to foreign ministers of UNASUR Member States participating in the mission, Rodriguez said that Paraguay fit in Articles 1, 5 and 6 of the Protocol on Democratic Commitment, indicating no regional support for the development of the Paraguayan case.

26 [o neo golpismo apresenta] menor uso da violência que no passado; liderança civil, podendo contar com participação indireta dos militares; manutenção de alguma aparência institucional; ausência da participação ostensiva de uma potência (EUA); e o objetivo de resolver de forma rápida algum tipo de impasse social ou político grave (LIMA, 2012, p. 1).

27 “não pôde dar um rumo diferente aos acontecimentos. [...] o que vimos é que já há uma decisão tomada, um golpe de Estado” (RODRIGUEZ, 2012, p. 1). 
Based on the democratic clause, the South American organization decided to suspend Paraguay. UNASUR Member States ratified the suspension ${ }^{28}$ of Paraguay until the restoration of democratic order, which they expected to happen after the 2013 elections. Such decision created an unusual situation, since Paraguay was responsible for the pro-tempore presidency of UNASUR. Peru faced with this standoff, had to take over the continuing presidency rotation stipulated by the organization.

Despite the suspension, UNASUR Member States decided not to impose economic or trade sanctions to Paraguay, because such measures would only further harm the Paraguayan people and increase political and social tensions. This decision however faced internal disagreements. The Ecuadorian President expressed the need of full compliance with the Protocol on Democratic Commitment, which included the suspension of economic relations as a way to curb coup movements in the region. On the other hand, Brazil and Argentina lobbied against economic measures, since both countries have strategic interests - mainly related to the energy sector - in Paraguay. In the end, the position of Brasilia and Buenos Aires prevailed.

The Paraguayan case was the first failure of UNASUR in preventing the interruption of the democratic order in South America. It highlighted the difficulties of acting in a context of neogolpismo, which eliminates the use of armed forces and uses the fragility of democratic institutions in some countries, making it difficult to characterize it as a coup. On the other hand, the existence of strong national interests made it difficult for the Organization to deal with the crisis. Both factors helped to build UNASUR ambiguous reaction. That is, the organization provided a quick diagnosis of the crisis and it was strong in the discursive level; however, its proposal for overcoming the crisis and developing conciliatory alternatives was weak.

Democracy in South America in general, and of Paraguay, in particular, has not been strengthened. The situation might be seen from the perspective of the organization's weakness in dealing with the interests of South American states. However, it is clear that UNASUR actions were important for the exercise of regional autonomy, as the organization was the main interlocutor between the parties. As in previous events, the South American countries dismissed

28 It is important to mention that the president of Paraguay, Federico Franco, questioned the suspension based on the alleged illegality of UNASUR democratic clause, since it had not been approved by the Paraguayan Parliament, therefore, would not be valid. 
extra-regional interference - in particular the US. Although it has failed in terms of finding a solution to the crisis, the UNASUR creating room for effective dialogue in South America.

\section{The Venezuelan crisis (2014-2015)}

The last years of Hugo Chavéz's government marked the slowing down of the Venezuelan economy. The death of Chavez, in March 2013, raised further doubts about the survival of his development model. However, the former Venezuelan leader managed to leave a successor. Nicolas Maduro reached the presidency of Venezuela committed to advancing the Chavism in face of the evident economic crisis.

In February 2014, a series of protests took place against Maduro's government, led mainly by Leopoldo López, the leader of the right-wing party Voluntad Popular. Among other things, protesters demanded a solution to the economic crisis in the country, caused by the decline in government revenues in face of falling commodity prices on the international market.

It is important to mention that the Venezuelan economy is strongly dependent on resources from oil sales. This market has been marked by disputes of Petroleum Exporting Countries (OPEC) and the US due to the North American shale oil and gas. This situation has brought down oil price in recent years. As a result, instabilities in the oil market have had negative impact in the Venezuelan economy. In recent years, the country has faced a staggering rise in inflation rate ${ }^{29}$, decline in exports ${ }^{30}$ and shortages of essential items in retail markets (IMF, 2015).

The protests that happened between February and June 2014 left the total of 43 people dead and 878 injured (AMNESTY INTERNATIONAL, 2015). One of the leaders of the demonstrations, Leopoldo López, has been accused of incitement, conspiracy and attempted coup what culminated in his arrest by the Venezuelan government. López has handed himself and has been arrested at a prison in Caracas.

Given the instability in Venezuela, Ecuadorian President Rafael Correa has called an UNASUR extraordinary meeting to address the issue. During the inauguration ceremony of the Chilean Michelle Bachelet, the worsening situation

29 According to data from the International Monetary Fund (IMF) in its World Economic Outlook Database, Venezuela's inflation was 56.193\% (in 2013), 69.829\% (in 2014) and the forecast for 2015 is $55.914 \%$ (IMF, 2015).

30 In 2013, the volume of exports fell $6.17 \%$. In 2014, the drop was $0.189 \%$. It is expected a slight recovery in 2015 (IMF, 2015). 
in the Andean country was discussed. In an official statement, the organization rejected the violence and expressed condolences to victims' families, as well as solidarity to the Venezuelan people and the democratically elected government (UNASUR, 2014).

The resolution signed at the Extraordinary Meeting of the UNASUR Council of Foreign Ministers on Venezuela approved five points: 1) support the Venezuelan government's efforts to establish dialogue with opposition forces and social movements; 2) creation of a mission to mediate negotiations, following Venezuela's request; 3) statement of the Pro Tempore Presidency to organize the work of the Council of Foreign Ministers to act on the issue; 4) reporting and requesting information about activities of Foreign Ministers to mediate the conflict; and 5) a statement of concern about threats to the independence and sovereignty of Venezuela (UNASUR, 2014).

The UNASUR sent diplomatic missions composed of foreign ministers of Brazil, Colombia and Ecuador, in addition to the current Secretary General of UNASUR and former Colombian President Ernesto Samper. The organization has taken two distinct courses of action. First, to mediate negotiations between Maduro's administration and opposition forces. Second, to negotiate with the US the end of economic sanctions imposed by Washington to Venezuela.

In early 2015, Obama said the situation in Venezuela was a "national emergency [...]. Unusual and extraordinary threat to the national security and foreign policy" (OBAMA, 2015, p. 1, free translation) ${ }^{31}$. In addition, the US president imposed sanctions against officials of Venezuela, as the freezing of economic transactions, as well as prohibition to enter into the United States territory. These sanctions are linked to Venezuela Defense of Human Rights and Civil Society Act, signed by Obama in December 2014.

Relations between Washington and Caracas have been unstable since the beginning of Chavism. After the 2014 protests, the situation has deteriorated mainly due to Maduro accused the US of interference and support for coups in Venezuela. Even though, Maduro requested UNASUR mediation for improving his relations with the US, making the assessment of the Venezuelan situation even more complex.

In March 2015, the UNASUR condemned the US classification of Venezuela as a security problem and rejected sanctions imposed by Washington. At the same

31 “emergência nacional [...]. Ameaça não usual e extraordinária à segurança nacional e à política exterior" (OBAMA, 2015, p. 1). 
time, it requested dialogue with the US. The UNASUR's requests seem not to have echoed in the northern portion of the continent, demonstrating that it is not yet strong enough to dialogue with the superpower. In addition, it is important to mention the curious fact that the Secretary General of UNASUR has not been allowed to enter the US territory since 1996, when his visa has been suspended for involvement with the Colombian drug trafficking (COSTA, 2015).

Although the attempt to negociate with the USA shows the evident fragility of the organization, the internal context is slightly more encouraging. The UNASUR has sent two missions to Venezuela, but the actual results are controversial. On the one hand, it has entitled both by Maduro and opposition. In 2014, it held negotiations between the parties and set some concrete solutions, such as the release of prisoners, no use of lethal weapons by government military forces and reestablishment of dialogue. However, opposition accused Maduro of not fulfilling agreements, generating more instability.

The UNASUR put pressure on the Venezuelan president to implement the partial renewal of public authorities, who were with expired mandates (MEZA, 2015). Maduro allowed the selection of new directors to the National Electoral Council (CNE), the Supreme Court and the Comptroller General, important institutions for the functioning of the democratic order. However, Maduro was accused of hindering opposition's access to these posts.

On the other hand, the UNASUR compromised its action in managing the Venezuelan case due to some negative statements by Samper in relation to members of the Venezuelan opposition. Malamud (2015, p. 1, free translation) accuses the Secretary General of “abandoning the equidistance, being much closer to Maduro's government than to opposition forces". ${ }^{2}$ This perception complicated mediation attempts, since the UNASUR has been one of the few organizations involved in resolving regional tensions. The organization cannot afford the price of losing symbolic capital in a period of economic and internal crisis of its members, which has led to near paralysis of the organization.

Despite the criticism, the UNASUR put strong pressure on Caracas for holding parliamentary elections, which is seen as a solution to the crisis and means to normalize the democratic order in the country. In June 2015, the organization made a series of announcements emphasizing the urgency of elections. The organization said it "is going to keep on defending through [...] diplomatic channels the

32 "abandonar a equidistância, mostrando-se muito mais próximo do governo Maduro do que das forças de oposição” (MALAMUD, 2015, p. 1). 
democratic institutions and the right of Venezuelans to resolve peacefully their own differences" (UNASUR, 2015a, p. 1, free translation). ${ }^{33}$

On June 22nd, 2015, the organization welcomed Venezuela by setting a date for the elections - one of the points agreed in negotiations with the opposition -, scheduled for December 6th, 2015. The UNASUR declared that "will implement an immediate Election Monitoring mission which was requested by the president of CNE and the Chancellors Committee of Brazil, Colombia and Ecuador" (UNASUR, 2015b, p. 1, free translation). ${ }^{34}$ Another statement, issued on June 24, 2015, the organization stressed the importance of parliamentary elections and reiterated its "fundamental commitment to ensure the effectiveness of peace, democracy and human rights in the region" (UNASUR, 2015c, p. 1, free translation). ${ }^{35}$

Venezuelan elections of November 2015 took place without major hassles. The Election Monitoring Mission of UNASUR monitored the elections and, more importantly, the calculations of votes and declaration of winners. It is important to note that the result of this election was a major defeat for Chavism. Opposition was largely successful, generating fear in the region for possible reactions from Maduro's administration. However, the Venezuelan government conceded defeat; the first one since the dissolution of the old Congress in 2000.

Despite criticisms regarding an alleged omission, lenient reaction or dubious position of its Secretary-General, it is important to note that UNASUR has provided great contributions to the management of the Venezuelan crisis. The organization used diplomatic channels and search for consensus, which are organization's basic elements. The Venezuelan case was crucial to test the UNASUR action ability in a period of severe economic crisis and changes in domestic politics in the continent.

\section{Conclusiones}

Regionally, the UNASUR has become the central space for discussions of South American problems. Its constant participation as conflicts mediator has strengthened its pacifying feature. Even in face of limitations and flaws, the

33 "seguirá defendendo através de [...] canais diplomáticos a institucionalidade democrática do país, e o direito dos venezuelanos de solucionar de forma pacífica suas próprias diferenças” (UNASUL, 2015a, p. 1).

34 "porá em prática imediatamente uma Missão de Acompanhamento Eleitoral que foi solicitada pela própria presidenta do CNE, a Comissão de Chanceleres do Brasil, Colômbia e Equador” (UNASUR, 2015b, p. 1).

35 "compromisso fundamental de assegurar a vigência da paz, da democracia e dos direitos humanos na região" (UNASUL, 2015c, p. 1). 
organization has demonstrated increasing authority to intervene in regional crisis, especially with regard to destabilization of the democratic order.

Increased legitimacy of the UNASUR as conflicts mediator is accompanied by the decrease of regional role played by the OAS. Although the hemispheric organization is older and has a more consolidated institutional architecture, counting on protection mechanism and promoting democracy, the UNASUR has occupied - albeit with severe flaws - this space.

The emergence of UNASUR as a regional authority is remarkable. Its performance has been based on the appeasement of the crisis, encouragement of dialogue and rapid search for solutions with participation of member states. The organization is informed by realpolitik, based on a relatively efficient and flexible method for conflict resolution. In all cases presented, the organization tried to mobilize the region rapidly to make decisions and build consensus, demonstrating that its process of integration depends on the defense and promotion of democracy.

During the crises in Bolivia and Ecuador this attitude was very evident. In relation to Paraguay, the UNASUR also sought dialogue and solutions quickly. Although it has not reached its goal in the Paraguayan case, the organization has shown that it has mechanisms to promote democracy at the regional level. However, it proved to be weak in dealing with interests of economically strong countries - Brazil and Argentina - in its mission to promote the South American democratic order.

Furthermore, the complexity of Venezuelan politics prevents a quick decision of UNASUR, as it involved an increasingly isolated and violent government, a dubious opposition, allegations of the US interference, and the severe economic crisis. The Venezuelan case shows the UNASUR's weakness. The organization, which has worked based on the presidential voluntarism, seems not to have the previous power.

During this period of political and economic crisis in South American countries (especially Argentina, Brazil and Venezuela), the UNASUR seems stuck on the South American problems. The resolution of the Venezuelan conflict was linked to the very progress of the organization; a failure of perception may mean the paralysis of UNASUR and compromise its goals. Thus, the future of this integrative project becomes dependent on its ability to maintain democratic order in the region. 


\section{References}

AMNESTY INTERNATIONAL. Venezuela: Los Rostros de la Impunidad. A un año de las protestas, las víctimas aún esperan justicia. Amnesty International Publications. 2015. Disponível em: < https://anistia.org.br/wp-content/uploads/2015/03/Venezuelareport-2015.pdf > . Acesso em: 1 out. 2017.

BRAZIL. Ministério das Relações Exteriores / Fundação Alexandre Gusmão. Declaración del Cuzco sobre la Comunidad Sudamericana De Naciones. Brasília: FUNAG. 2005. CEPEDA, Miño; PAZ, Juan. El 30-s: intento de golpe de Estado en Ecuador. In Observatorio Latinoamericano, Dossier Ecuador, v. 7, n. 6, p. 14-25. 2011. Disponível em: http://iealc.sociales.uba.ar/observatorio-latinoamericano/observatorio-latino americano-no-7-dossier-ecuador-junio-de-2011/ > . Acesso em: 30 set. 2017.

CHAVEZ, Hugo. (2010) Cumbre de Unasur acuerda un protocolo contra golpes de Estado. BBC Mundo. Disponível em: < http://www.bbc.com/mundo/noticias/2010/11/101126_ colombia_ecuador_relaciones_restablecimiento_unasur_jg.shtml >. Acesso em: 11 out. 2017.

CORREA, Rafael. (2010) Cumbre de Unasur acuerda un protocolo contra golpes de Estado. BBC Mundo. Disponível em: < http://www.bbc.com/mundo/noticias/2010/11/101126_ colombia_ecuador_relaciones_restablecimiento_unasur_jg.shtml >. Acesso em: 11 out. 2017.

COSTA, Mariana Timóteo da. Unasul, um bloco regional na UTI. O Globo. 2015. Disponível em: < http://oglobo.globo.com/mundo/unasul-um-bloco-regional-na-uti-15534816> . Acesso em: 11 out. 2017.

DOMINGUES, José Maurício. Bolívia às Vésperas do Futuro. Análise de Conjuntura OPSA, n. 9. 2008. p. 2-14. Disponível em: < http://observatorio.iesp. uerj.br/images/pdf/ analise/52_analises_AC_n_09_set_2008.pdf >. Acesso em: 11 out. 2017.

FLACSO. Dossier Grupo de Rio. Cuadernos Integración de América Latina. San José: FLACSO, 122 p. 2008. Disponível em: < http://unpan1.un.org/intradoc/groups/ public/documents/icap/unpan027079.pdf > . Acesso em: 10 out. 2017.

GAIO, Gabrieli. A destituição de Lugo: atores e eventos. Dossiê Paraguai. Observador On-line. v.7, n. 6. 2012. Disponível em: < http://observatorio.iesp. uerj.br/images/ pdf/observador/observador_v_7_n_06_2012.pdf > . Acesso em: 30 set. 2017.

GIRALDI, Renata. Paraguai anuncia que vai combater guerrilha EPP. Portal EBC - Empresa Brasil de Comunicação, Agência Brasil. 2013. Disponível em: < http://memoria.ebc.com.br/ agenciabrasil/noticia/2013-08-21/paraguai-anuncia-que-vai-combater-guerrilha-epp > . Acesso em: 13 out. 2017. 
GUIMARÃES, Débora; BARROS, Flávia; PINTO, Julio. Democracia na América Latina: desafios e perspectivas. Revista Sociedade e Estado. Vol. 29, Número 1, janeiro/abril 2014. Disponível em: < http://dx.doi.org/10.1590/S0102-69922014000100002 > . Acesso em: 13 mar. 2018.

GUIMARÃES, Samuel. Integração regional e acordos de livre comercio. In: SARTI, I.; MARTINS, J.; LESSA, M.; CARVALHO, G. (orgs.) Os desafios da Integração Sulamericana: autonomia e desenvolvimento. Rio de Janeiro: Folio Digital, 2014.

HERMET, Guy. A democratização dos países emergentes e as relações entre o Estado, as OIGs e as ONGs. In: MILANI, Carlos; ARTURI, Carlos; SOLINIS, Germán (orgs). Democracia e Governança Mundial. Que regulações para o século XXI? Porto Alegre: Ed Universidade UFRGS, 2002.

HONNETH, Axel. Democracia como cooperação reflexiva. John Deweyt e a teoria democrática hoje. In: SOUZA, Jesse (org.) Democracia Hoje: novos desafios para a teoria democrática contemporânea. Brasília: Editora Universidade de Brasília, 2001.

IMF. World Economic Outlook Databases, 2015. Washington: IMF, 2015. Disponível em: < https://www.imf.org/external/ns/cs.aspx?id = 28 > . Acesso em: 27 abr. 2018.

ISAGS. Unasul. Disponível em: < http://www.isags-unasursalud.org/interna.asp?lang= $1 \&$ idArea $=38>$. Acesso em: 15 out. 2017.

LIMA, Maria Regina Soares de. Precedente Perigoso. Dossiê Paraguai, vol. 7, nº 06. 2012. Disponível em: < http://www.plataformademocratica.org/Publicacoes/22369.pdf > . Acesso em: 15 out. 2017.

LUGO, Fernando. Impeachment de Lugo. Folha de São Paulo. Opinião. 23 jun. 2012. Disponível em: < http://www1.folha.uol.com.br/fsp/opiniao/50407-impeachmentde-lugo.shtml > . Acesso em: 12 out. 2017.

SILVA, Luiz Inácio. Discurso do Presidente da República, Luiz Inácio Lula da Silva, na abertura do debate geral da $63^{a}$ Assembleia Geral das Nações Unidas. 2008. Disponível em: < http://www.itamaraty.gov.br/sala-de-imprensa/discursos-artigos-entrevistase-outras-comunicacoes/presidente-da-republica-federativa-do-brasil/0744638582379discurso-do-presidente-da-republica-luiz-inacio/? searchterm $=$ discurso $\% 20$ do $\% 20$ presidente \%20lula \%20assembl\% C3\% A9ia\%20geral > . Acesso em: 12 out. 2017.

MALAMUD, Carlos. Nuevo fracaso de Unasur en Venezuela. Infolatam. 2015. Disponível em: < http://www.infolatam.com/2015/03/08/nuevo-fracaso-de-unasur-en-venezuela/ > . Acesso em: 15 out. 2017.

MERCOSUR. Declaração Presidencial sobre Compromisso Democrático no Mercosul. 1996. Disponível em: < http://www.mercosur.int/innovaportal/file/4677/1/cmc_1996_ acta01_declara-presiden_pt_compdemocratico.pdf >. Acesso em: 18 out. 2017. 
MEZA, Alfredo. A Unasul será mediadora entre a oposição e o Governo venezuelano. 2015. Disponível em: El País. < http://brasil.elpais.com/brasil/2015/03/04/internacional/ 1425499467_729230.html >. Acesso em: 11 out. 2017.

MIRANDA, Mario Ângelo Brandão de Oliveira. As significações e usos do conceito de democracia no ambiente político sul-americano atual e sua relevância no contexto da integração regional. In: LAPSKY, Igor; SCHURSTER; Karl; SILVA, Francisco Carlos Teixeira da (orgs). Instituições sul-americanas no tempo presente: caminhos da integração. Rio de Janeiro: Mauad, 2013.

MORALES, Evo. Cúpula da Unasul entra em acordo unânime de apoio à Bolívia. 2008. Folha de São Paulo. Mundo. Disponível em: < http://www1.folha.uol.com.br/ mundo/2008/09/445266-cupula-da-unasul-entra-em-acordo-unanime-de-apoio-abolivia.shtml > . Acesso em: 17 out. 2017.

OBAMA, Barack. Obama decreta novas sanções contra altos funcionários da Venezuela. El País, Washington. 2015. Entrevista concedida a Silvia Ayuso. Disponível em: < http:// brasil.elpais.com/brasil/2015/03/09/internacional/1425919831_255459.html > . Acesso em: 13 out. 2017.

RODRIGUEZ, Alí. Enviado da Unasul diz que situação no Paraguai é de 'golpe'. BBC Mundo. Caracas. Entrevista concedida a Claudia Jardim, 2012. Disponível em: http://www.bbc.com/portuguese/noticias/2012/06/120622_lugo_unasul_cj_ dt.shtml > . Acesso em: 12 out. 2017.

SARAIVA, Miriam Gomes. Procesos de integración de América del Sur y el Papel de Brasil: los casos del Mercosur y la Unasur. Revista CIDOB d'afers internacionals, n. 97-98, p. 87-100. 2012. Disponível em: < https://www.cidob.org/es/articulos/ revista_cidob_d_afers_internacionals/97_98/procesos_de_integracion_de_america_ del_sur_y_el_papel_de_brasil_los_casos_del_mercosur_y_la_unasur > . Acesso em: 10 out. 2017.

SARTI, Ingrid. Integração Sulamericana: os desafios de um projeto estratégico. In: SARTI, I.; MARTINS, J.; LESSA, M.; CARVALHO, G. (orgs.) Os desafios da Integração Sulamericana: autonomia e desenvolvimento. Rio de Janeiro: Folio Digital, 2014.

SERBIN, Andrés. A América do Sul em um mundo multipolar. A Unasul é uma alternativa?. Nueva Sociedad, n. 219, v. 1-2, 2009. Disponível em: < http://nuso.org/media/ articles/downloads/p7-1_1.pdf > . Acesso em: 20 out. 2017.

UNASUR. Protocolo Adicional ao Tratado Constitutivo da Unasul sobre o Compromisso com a Democracia. Georgetown, Guiana. (2010a) Disponível em: < http://www.unasursg. org/images/descargas/DOCUMENTOS \% 20CONSTITUTIVOS \% 20DE \% 20UNASUR/ Protocolo-Adicional-al-Tratado-Constitutivo-de-UNASUR-sobre-Compromiso-con-laDemocracia-opt.pdf > . Acesso em: 12 out. 2017. 
. Declaración de Buenos Aires. Buenos Aires, Argentina. (2010b) Disponível em: < http:// www.ambito.com/diario/aw_documentos/archivospdf/2005/id_doc_5566.pdf > . Acesso em: 13 out. 2017.

. Resolución $N^{o} / 2014$. Santiago do Chile. (2014) Disponível em: < http://isags-unasul. iphotel.info/noticias_interna.asp?idArea $=2 \&$ lang $=1 \&$ idPai $=7270>$. Acesso em: 13 out. 2017.

. Comunicado Oficial del Secretario General de UNASUR. (2015a) Disponível em: < http://www.unasursg.org/es/node/286. Acesso em: 13 out. 2017.

. UNASUR inició conformación de la Misión de Acompañamiento para las elecciones de Venezuela, tras pedido formal del CNE. (2015b) Disponível em: < http://www. unasursg.org/es/node/300 > . Acesso em: 12 out. 2017.

. Comunicado de la Secretaría General de Unasur sobre las Elecciones en Venezuela. (2015c). Disponível em: < http://www.unasursg.org/es/node/297 > Acesso em: 12 out. 2017.

VIGEVANI, T.; RAMANZINI, H. Autonomia, Integração Regional e Política Externa Brasileira: Mercosul e Unasul. DADOS - Revista de Ciências Sociais, vol. 57, n. 2, 2014. Pp. 517-552. Disponível em: < http://www.scielo.br/pdf/dados/v57n2/ a08v57n2.pdf $>$. Acesso em: 13 out. 2017. 